
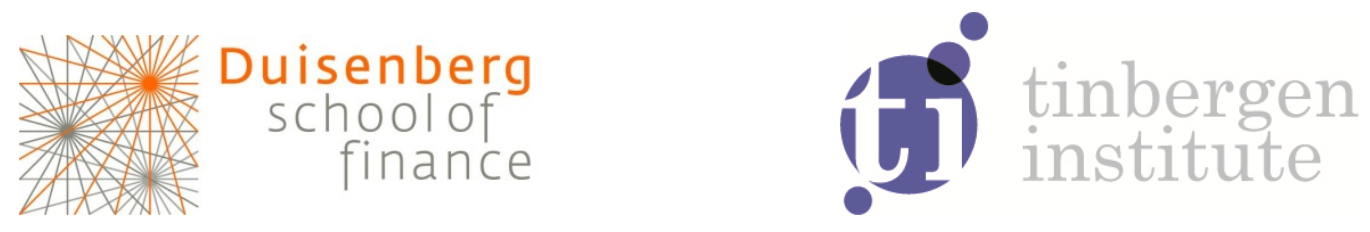

Duisenberg school of finance - Tinbergen Institute Discussion Paper

TI 12-022/2/DSF3 1

On Risk, Leverage and Banks:

Do highly Leveraged Banks take on Excessive Risk?

Martin Koudstaal,, 2

Sweder van Wijnbergen ${ }^{1,3}$

1 Tinbergen Institute;

2 Double Effect;

3 Amsterdam School of Economics, VU University Amsterdam. 
Tinbergen Institute is the graduate school and research institute in economics of Erasmus University Rotterdam, the University of Amsterdam and VU University Amsterdam.

More TI discussion papers can be downloaded at http://www.tinbergen.nl

Tinbergen Institute has two locations:

Tinbergen Institute Amsterdam

Gustav Mahlerplein 117

1082 MS Amsterdam

The Netherlands

Tel.: +31(0)205251600

Tinbergen Institute Rotterdam

Burg. Oudlaan 50

3062 PA Rotterdam

The Netherlands

Tel.: +31(0)10 4088900

Fax: +31(0)104089031

Duisenberg school of finance is a collaboration of the Dutch financial sector and universities, with the ambition to support innovative research and offer top quality academic education in core areas of finance.

DSF research papers can be downloaded at: http://www.dsf.nl/

Duisenberg school of finance

Gustav Mahlerplein 117

1082 MS Amsterdam

The Netherlands

Tel.: +31(0)20 5258579 


\title{
On Risk, leverage and banks: Do highly leveraged banks take on excessive risk?
}

\author{
Martin Koudstaal \\ Tinbergen Institute \& Double Effect \\ and \\ Sweder van Wijnbergen* \\ University of Amsterdam \& Tinbergen Institute
}

March 2012

\begin{abstract}
This paper deals with the relation between excessive risk taking and capital structure in banks. Examining a quarterly dataset of U.S. banks between 1993 and 2010 , we find that equity is valued higher when more risky portfolios are chosen when leverage is high, and that more risk taking has a negative impact on valuation of the debt of highly leveraged banks. We find no evidence that deposit insurance is encouraging risk taking behaviour. We do find that banks with a more troubled loan portfolio take on more risk. Banks whose share price has slumped tend to gamble for resurrection by increasing the riskiness of their asset portfolios. The results suggest that incentives embedded in the capital structure of banks contribute to systemic fragility, and so support the Basel III proposals towards less leverage and higher loss absorption capacity of capital.
\end{abstract}

Key words: $\quad$ bank fragility, risk shifting, deposit insurance, gambles for resurrection

JEL codes: $\quad$ G21, G28, G32

* corresponding author, Email: s.j.g.vanwijnbergen@uva.nl; van Wijnbergen thanks the Gieskes-Strijbis foundation for research support 


\section{Introduction}

The 2007/2008 credit crisis and the ensuing large scale government bail outs of distressed banks have once again focused the public debate on possibly excessive risk taking by banks. To avoid widespread economic collapse, governments throughout the USA and Europe felt compelled to massively intervene with public guarantees and recapitalizations to bail out financial institutions considered "Too Big To Fail". Moreover, several systemwide measures were introduced, such as interbank loan guarantees and/or higher deposit insurance limits, to further enhance system stability (cf. Brunnermeier (2009) for an early overview of the credit crisis). While governments and central banks initially focused on rescuing the financial system and limiting fall out towards the "real economy", the large costs and risks to which tax payers were exposed have triggered widespread debates on how to tighten regulation so as to minimize chances of such a large scale series of mishaps occurring again. The BIS has only recently published a substantially tightened version of its globally used supervision framework for banks (Basel III) in which capital requirements are tightened and a variety of measures are proposed to discourage the taking on of liquidity risk.

More recently, the issue of excessive bank risk taking has come up again as debt overhang problems on the Southern rim of the Eurozone spilled over into countries that initially were thought to be safe through cross border losses in banks still engaged in a fragile recovery process from the capital destruction that took place during the credit crisis. IMF managing director Lagarde referred to the cross border risk exposure of fragile banks as "chains of contagion" (Financial Times, 2011).

A key question complicating the policy debate is whether bank fragility is a systemic feature, unavoidable if the benefits of a sophisticated system of financial intermediation are to be reaped, or whether incentives within that financial system are encouraging socially undesirable risk taking with subsequent need for regulation. Ranciere e.a. (2008) have argued that there is a trade off on a macroscale too, arguing that crisis-prone countries in the long term grow faster because the benefits of financial intermediation outweigh the disadvantages of increased fragility that it also leads to. Yet the financial intermediation literature has long argued that information asymmetries may lead to excessive risk taking, as limited liability effectively implies a put option on the firm's assets, written by debt holders to the firm's management and shareholders. The origin of this insight goes back a long way in the corporate finance literature (Jensen and Meckling (1976), Merton (1974)) and is not specific to banks but applies to any mixed capital structure firm in an asymmetric information environment. But the issue is likely to be much more important in financial firms for a variety of reasons. 
First, banks as a group play a crucial role in the functioning of the economy as a whole, with potentially very large social costs after sudden disruptions in the functioning of bankservices on a systemic scale. Reinhard and Rogoff (2009) estimate that on average recovery from a downturn is prolonged by some 5 years when coinciding with a financial crisis. The second reason concerns individual banks: although the predominant rationale for government intervention is based on the desire to avoid systemic disruptions, there is widespread concern that even individual failures may set off chain reactions threatening the system as a whole (Diamond and Rajan (2011)). Banks, by the nature of their business, are highly exposed to maturity mismatch and liquidity risk: taking on such mismatches and risks is in fact what banks do (Diamond and Rajan (2001)). But that makes them also vulnerable to firesales and sudden liquidity dry-ups elsewhere in the sector.

A distinguishing feature of the two lines of reasoning is the link between capital structure and risk taking. If fragility is simply part of the business of financial intermediation per se rather than a socially damaging response to the combination of asymmetric information and debt finance, one should not expect debt structure to matter for the degree of risk taking observed in practice. If however debt structure is a serious driver of risk taking, skewing risk taking incentives towards taking on of more risk to the disadvantage of one class of financiers (and the tax payers forced to finance an eventual bail out), the case for policy intervention is much stronger. The issue complicates further once different debt classes enter into the fray. If risk shifting can be passed on to taxpayers, either through deposit insurance or through implicit promises of recaps sparing debt holders, the put option provided by debt holders to management/equity providers will not be priced into the debt contract, possibly raising ex ante incentives towards excessive risk shifting further.

The empirical literature on risk taking, financial fragility and capital structure is surprisingly small given the importance of the topic and the fact that issues have been discussed in the finance literature for decades already. The literature has either focused on non-financial firms (Chang et al. (2009)), or on financial firms but on other distinguishing characteristics than capital structure (e.g. Laeven and Levine (2009)). In this paper we intend to fill that gap by examining a large dataset of U.S. banks with data from the period between 1993 and 2010. We focus exclusively on banks because of their systemic importance, and because their leverage is so much higher than the leverage commonly observed in non-financial firms that the problem of risk shifting is likely to be much higher. An advantage of the time period covered is that we can use the Lehman bankruptcy and the turmoil that followed to better identify the link between risk shifting incentives and capital structure. 
The paper is organized as follows. First, section 2 will sketch the theoretical background underlying this paper and will outline the testable implications that are at the basis of the empirical analysis. Section 3 describes the data used, considers the applied empirical model and discusses the methodology used. In section 4 we present the results of this paper, while section 5 concludes.

\section{Theory}

The theoretical literature on risk shifting and capital structure goes back to the by now classic paper by Jensen and Meckling (1976). Managers and shareholders have an incentive to take on too much risk, substituting risky assets for safe assets, since they are protected from the left tail of the distribution by limited liability. Risk is shifted to the debt holder who implicitly writes out a put option to the manager/shareholder (see also Merton, 1974). Loading up more risk on the asset side increases the value of that put option. Financial institutions are special in that they typically are vastly more leveraged than non-financial firms, magnifying the risk shifting problem. On the other hand, a substantial part of bank debt constitutes of callable demand deposits. Diamond and Rajan (2001) argue that due to the disciplining impact of call deposits, banks can resolve liquidity problems that would arise in a direct lending setup. An issue is to what extent deposit insurance changes these incentives. In the empirical analysis that follows, we will distinguish between debt covered by deposit insurance and debt that is not so covered. We distill four testable hypotheses from this part of the theoretical literature:

\section{$\mathbf{H}_{1}$ - everything else equal, shareholders prefer riskier banks because of the higher value of the implicit put option extended by debt holders \\ $\mathbf{H}_{2}-\quad$ as a mirror image, debt holders are negatively affected by risk shifting since this reduces the value of their debt holdings \\ $\mathbf{H}_{3}$ - $\quad$ shareholders prefer higher leveraged banks since this offers more opportunities for risk shifting \\ $\mathbf{H}_{4}-\quad$ the level of bank risk taking is positively related to deposit insurance}

Diamond and Rajan (2001), Jensen and Meckling (1976) and Calomiris and Kahn (1991) argued that debt also decreases the moral hazard of managerial rent extraction. In more recent work, Acharya et al. (2011) combine the aforementioned models and show that if leverage is too low, debt holders lack incentives to monitor the manager since debt is essentially safe, while if leverage is too high, managers will like to substitute safer assets for riskier ones at the expense of debt holders. Hence, this tradeoff between the two types of moral hazard thus implies a 
privately optimal bank leverage ratio that is neither 'too low or too high'. We will empirically test the link between leverage, risk taking and shareholder value and the role deposit insurance plays in that relation.

An extreme form of excessive risk taking can be expected in distressed banks: Diamond and Rajan (2011) and Bruche and Lobet (2011) argue that banks gambled for resurrection after Lehman Brothers by holding on to risk assets even though selling them might have saved the bank. We will investigate the impact of Lehman and the ensuing financial distress on pricing and risk taking behavior. This view suggests that extreme risk taking should be influenced by balance sheet structure, but not necessarily by prior losses. Alternatively, one could also relate the incentive to gamble for resurrection (increased risk taking in distress situations) to the notion of loss aversion (see e.g. Kahneman and Tversky (1979); Tversky and Kahneman (1991, 1992). In that case prior losses should be the main driver of extreme risk taking. Of course if the distressed balance sheet condition is caused by prior losses, the two explanations cannot be distinguished. Thus, we can infer the following two extra hypotheses:

$\mathbf{H}_{\mathbf{5}}-\quad$ gambling for resurrection occurs low solvency banks with a high fraction of bad loans

$\mathbf{H}_{6}-\quad$ banks will engage in more risk taking after declines in their own share price

\subsection{Related Literature}

One of the few papers that has addressed bank risk taking empirically is Laeven and Levine (2009), who analyze the relationship of risk taking, ownership structure, and national bank regulations using a dataset of 270 banks across 48 countries. The authors find that banks with more powerful owners tend to take greater risks. Moreover, they only examined the biggest 10 listed banks per country and so cannot really distinguish by bank size and they have not looked at the importance of leverage or more generally capital structure, a key focal point of the currently ongoing policy debate and of our paper. Chang et al. (2009) examine financially distressed firms rather than banks and find that risk shifting behavior only exist in small financially distressed firms, but not in large financially distressed firms.

Furthermore, Chang et al. (2009) show that factors including shorter maturity debt and less growth options have significant effects on mitigating the risk shifting behavior in small distressed firms. Their results are highly relevant for banks, since through their deposit base banks often have a large part of their debt at very short maturity (call deposits). Moreover, their focus on financially distressed firms might limit the applicability of their findings to banks in general since financially distressed firms could well be structurally different from financially 
healthy firms (other than the difference in financial solidity), in which case the resulting sample selection bias would argue for caution in extending their results to firms in general.

\section{Data and Methodology}

In order to examine the relation between equity valuation and risk taking, we explored how market-to-book ratios (as a scaled measure of shareholder valuations) relate to the standard deviation of the Return on Assets, the latter serving as a proxy for the degree of risk taking by bank managers, and other control variables likely to influence market to book ratios. As to measures of managerial risk taking, we want to distinguish general market risk outside management control and aspects of the risk profile that are under management control. As a measure of market-risk we use the VIX volatility index; as a measure of risk under management control we use the standard deviation of the Return on Assets, ROA, which obviously depends on the portfolio choices made by bank management

We do not have direct observations on market prices for debt for our sample/time period, so we use S\&P short term and long term bond ratings as a proxy for the market value of the corresponding debt instruments and expore how they relate to our measure of risk taking. Furthermore, we test whether the relation between debt values and risk taking shifted after the Lehman bankruptcy. This is particularly relevant since the collapse of Lehman Brothers appears to have increased the level of asymmetric information in the market (see e.g. Flannery, 1996; Cassola et al., 2008). More specifically, Cassola et al. show that the market microstructure was significantly affected by the financial turmoil. Moreover, the Lehman Brothers failure also coincides with the increase in deposit insurance that was raised to $\$ 250,000$ in 2008 and was the first big bank that was not rescued by the U.S. government.

We also test whether the relation between valuation and risk taking shifted after Lehman, through the inclusion of an interaction term between the standard deviation of ROA and a Lehman Brothers dummy. Similarly, we include an interaction term between the standard deviation of ROA and leverage; it is plausible that there is a stronger relation between risk taking and valuation for more highly leveraged banks. We repeat this regression splitting the sample in high (above median value) and low (below median value) leverage banks. To assess the effect of deposit insurance $\left(\mathbf{H}_{4}\right)$ on risk taking, we regress the standard deviation of Return on Assets (ROA) on, among other variables, the level of insured deposits on the balance sheet as a proportion of total non-insured liabilities.

Furthermore, we test whether the effect of leverage on the standard deviation of Return on Assets (ROA) is different for banks that have a leverage ratio above the median level and banks 
that are leveraged below average. Acharya et al. (2011) predict the sign of the coefficient to be positive in the first case, and negative in the second.

To test for the gamble for resurrection hypothesis $\left(\mathbf{H}_{5}\right)$, the standard deviation of Return on Assets (ROA) will be regressed on the bad loan reserve ratio (over total assets) and leverage. The effect of more loan loss provisions for prospective asset losses on risk taking should be stronger for higher leveraged banks, since higher leverage creates more opportunities for risk shifting. The final hypothesis concerned the impact of negative share price performance on subsequent risk taking $\left(\mathbf{H}_{6}\right)$.

\subsection{Data Description}

In order to empirically explore the effects outlined above, we have collected quarterly data on banks from the Compustat annual industrial files on the WRDS database (SIC codes between 6000 and 6200) between 1993:3-2010:2. The year 1993 is chosen because this is the first year that risk based capital was fully implemented (Beatty and Liao, 2009). The sample is restricted to firms that are incorporated in the U.S.

As argued above, the main variable that represents shareholder valuation is market-to-book ratio, which is computed as the ratio of book value of assets (Compustat: ATQ) minus book value of equity (Compustat: SEQQ) plus the market value of equity (share price $\mathrm{x}$ shares outstanding, Compustat codes: PRCCQ and CSHOQ) divided over the book value of assets.

The debt variables that can provide insight into the relationship between risk factors and the cost of debt are the S\&P short term and long term ratings, which are extracted from Compustat and matched to the associated banks. In order to make them useful to analyze, a ordinal ranking has been assigned to the different ratings (see table 1, next page).

The first main risk variable is the standard deviation of return on assets (ROA), which is computed by measuring the standard deviation of the ROAs of the last 5 quarters, where return on assets is defined as net income (Compustat: NIC) over total assets (Compustat: ATQ).

The other main variable of interest is the VIX index, which is a proxy for the market's perception of the implied option volatility and thus serves as a market-based measure of riskiness. The daily VIX data was retrieved from Yahoo Finance and averaged per quarter since the company data was only available per quarter. Finally, the dummy LEH is 1 starting from Q4 of 2008 since Lehman Brothers collapsed in September 2008.

With respect to the firm-level control variables, liquidity ratios (LIQratio) are defined as the ratio of cash and marketable securities (Compustat: CHEQ) over total assets (Compustat: ATQ). Liquidity ratios are included in the equation since they seem to have signaling values (see e.g. Bijkerk and Van Wijnbergen, 2012). Furthermore, SIZE is extracted from Compustat as well and 


\begin{tabular}{cccc}
\hline \hline ST Rating & Value & LT Rating & Value \\
\hline A-1+ & 11 & AAA & 21 \\
A-1 & 10 & AA+ & 20 \\
A-2 & 9 & AA & 19 \\
A-3 & 8 & AA- & 18 \\
B & 7 & A+ & 17 \\
B-1 & 6 & A & 16 \\
B-2 & 5 & A- & 15 \\
B-3 & 4 & BBB+ & 14 \\
C & 3 & BBB & 13 \\
D & 2 & BBB- & 12 \\
SD & 1 & BB+ & 11 \\
& & BB & 10 \\
& & BB- & 9 \\
& & B+ & 8 \\
& & B & 7 \\
& & B- & 6 \\
& & CCC+ & 5 \\
& & CCC- & 3 \\
& & CC & 2 \\
& & SD & 1 \\
\hline \hline
\end{tabular}

\section{Table 1: Short Term (ST) and Long Term (LT) Ratings and Values}

is defined as the logarithm of total assets. Another control variable is general profitability, for which we have included the return on assets (ROA).

In order to identify structural differences in market-to-book valuations for specific types of banks (see e.g. Berger et al, 2008), we have included total leverage (LEV), which is computed as total liabilities (Compustat: LTQ) divided over total assets, and DEPratio, which is defined as the ratio of deposits (Compustat: DPTCQ) over non-insured liabilities (e.g. repos, commercial paper and long term debt). To test whether relative share price performance affects the standard deviation in ROA, the bank's return over the 5 previous quarters is computed (av5QRET).

Table 2 on the next page provides an overview of the final data sample, which consists of 42,467 firm-year observations. As one can observe, the average Market-to-Book ratio is 1.14, while the average standard deviation of ROA is 0.0018 and the average VIX is 21.53. The median S\&P short term bond rating is $\mathrm{A}-1$, while the median long term rating is $\mathrm{A}$.

Furthermore, it can be observed that there is not only more variation in the standard deviation of ROAs compared to the VIX index, but also in short term ratings versus the long term ones. The latter can be explained by the fact that there are more categories. To get a better grasp of the time dynamics of the variables, we look at the development of the average market-to-book 


\begin{tabular}{lcccr}
\hline Variable & Mean & Median & St.Dev & Obs \\
\hline MBratio & 1.142569 & 1.039463 & 1.725478 & 34754 \\
stdevroa & .0018206 & .00039 & .015667 & 16676 \\
VIX & 21.53127 & 21.36083 & 8.77457 & 42445 \\
S\&P short term & 9.897234 & 10 & 1.257338 & 4194 \\
S\&P long term & 15.55648 & 16 & 3.047021 & 5524 \\
& & & & \\
Controls & & & & \\
LIQratio & .068834 & .0438788 & .0920693 & 37809 \\
SIZE & 7.224195 & 6.80764 & 2.163319 & 38306 \\
LEV & .8785881 & .9078052 & .935015 & 38243 \\
DEPratio & 12.35354 & 5.42616 & 29.13608 & 31627 \\
ROA & -.0028384 & .00239 & .3174099 & 38306 \\
& & & & \\
\hline \hline
\end{tabular}

Table 2: Descriptive Statistics

ratio, standard deviation of ROA and the abovementioned relevant ratios over time. The result for the average Market-to-Book ratio is plotted in figure 1.

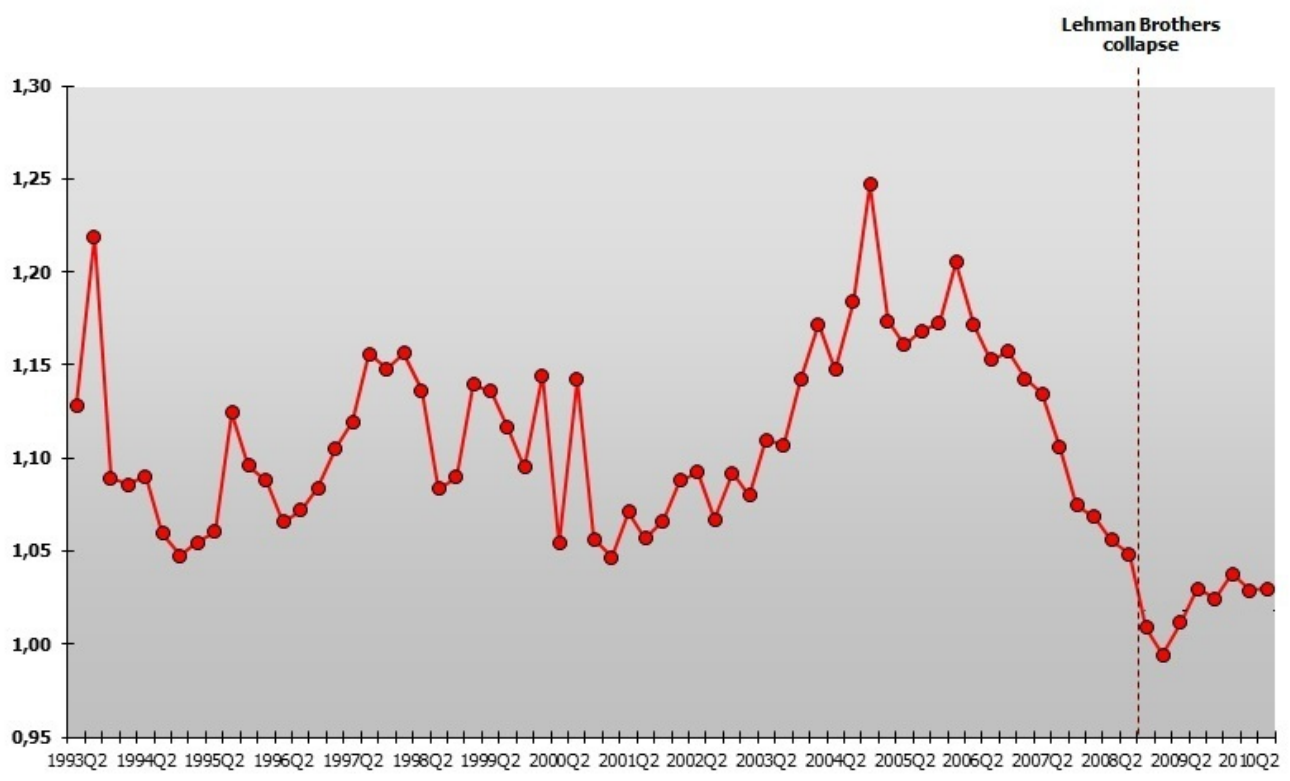

Figure 1: Average Market-to-Book Ratios

It can be verified that market-to-book ratios have declined on average after Lehman Brothers collapsed, but have recovered to (almost) the level just before Lehman Brothers went bankrupt. If we take a closer look at the standard deviation in ROA, we can find that the trend after Lehman seems negative, though the average standard deviation of ROA has also 
increased (see figure 2).

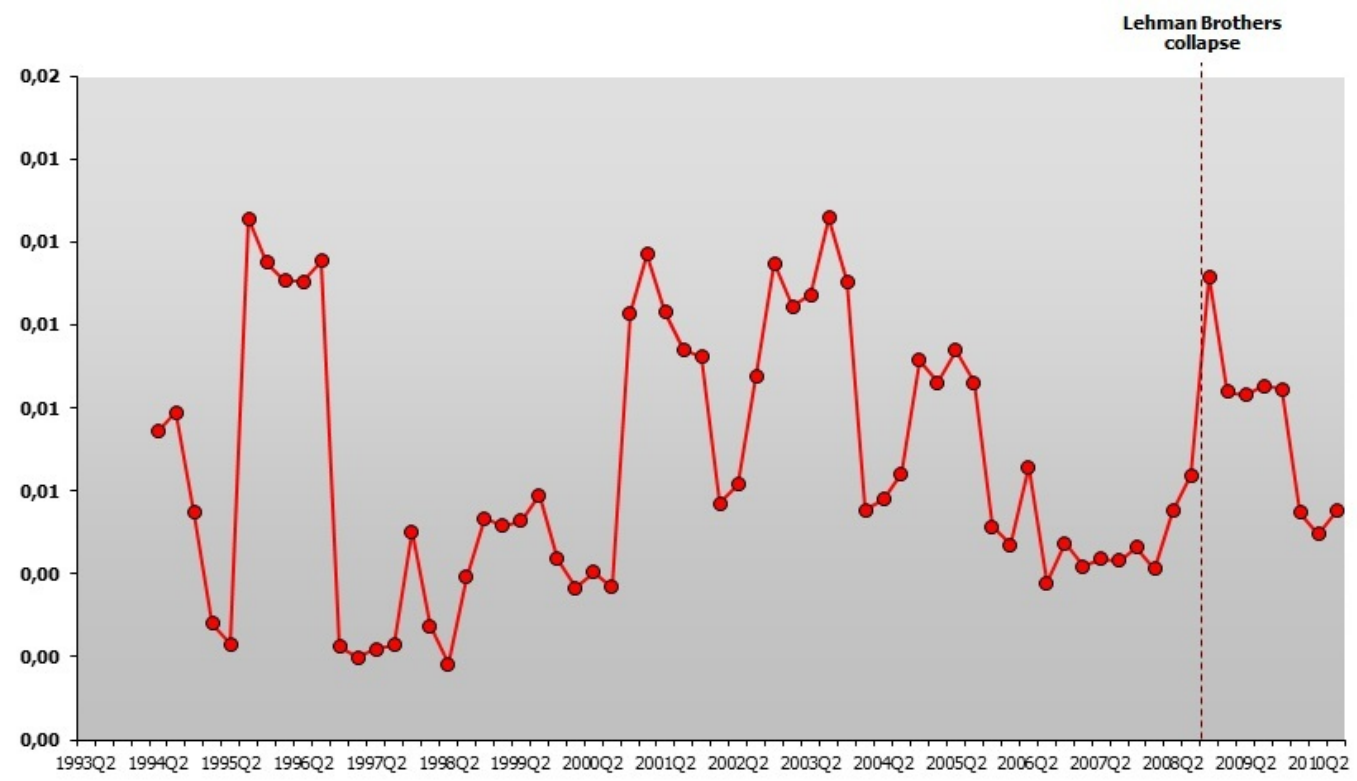

Figure 2: Average Standard Deviation of ROA

Furthermore, surprisingly, the levels of leverage have remained quite stable in general (see figure 3).

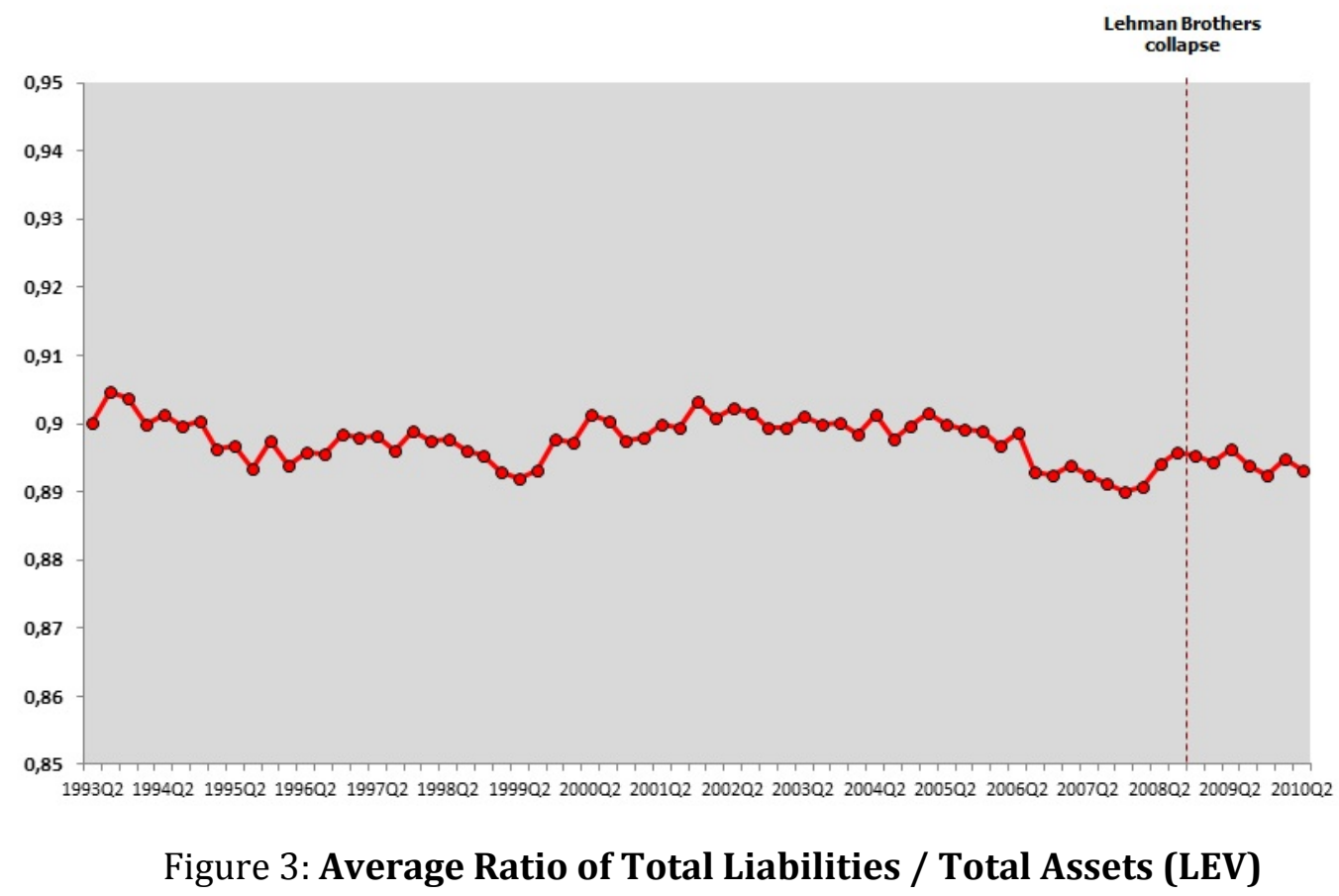


A different pattern can be observed for the ratio of reserves for asset losses over total assets, which has increased rapidly after Lehman Brothers (figure 4).

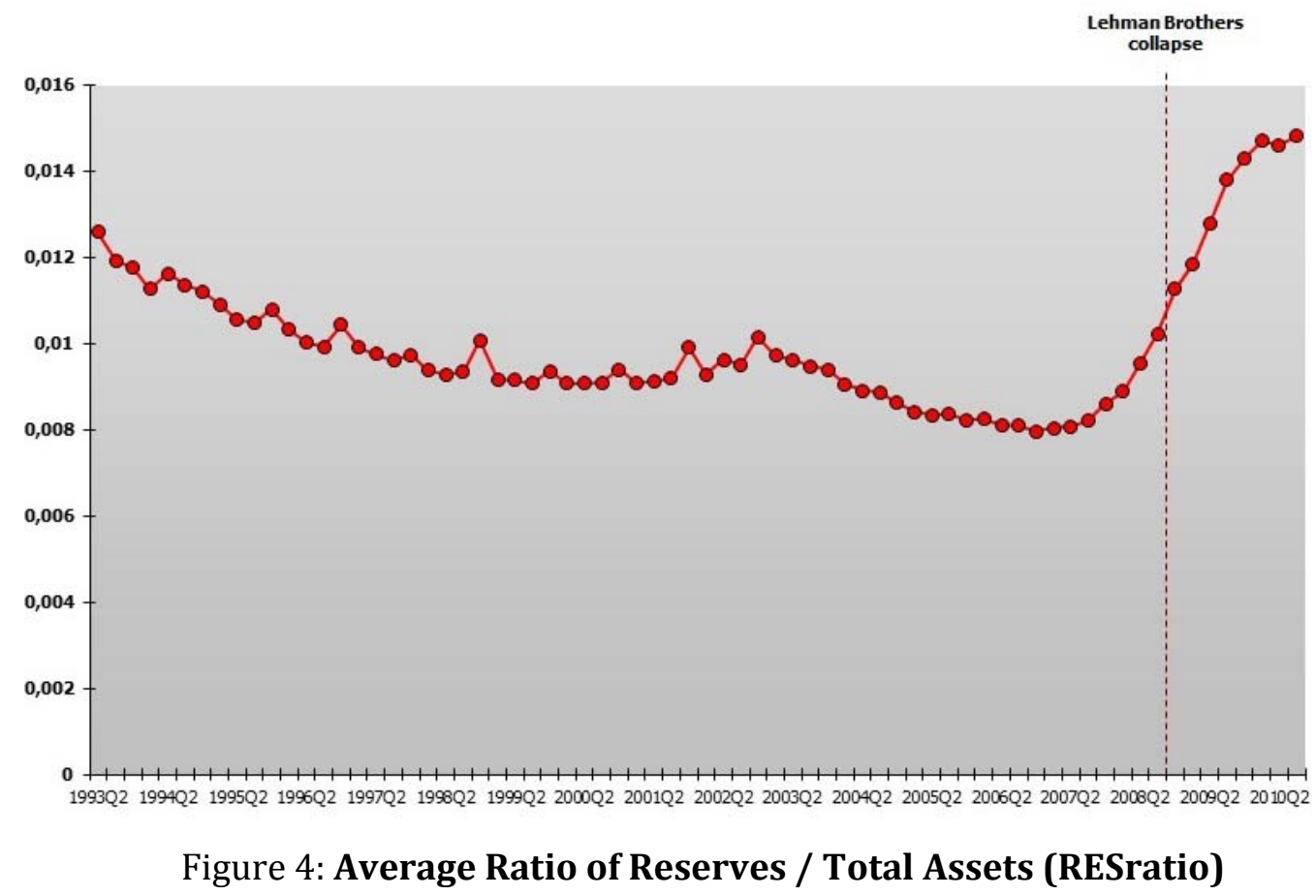

Finally, looking at the average VIX-index (see figures 5), we can see that the VIX-index skyrocketed after Lehman Brothers collapsed, but quickly returned to the pre-Lehman levels.

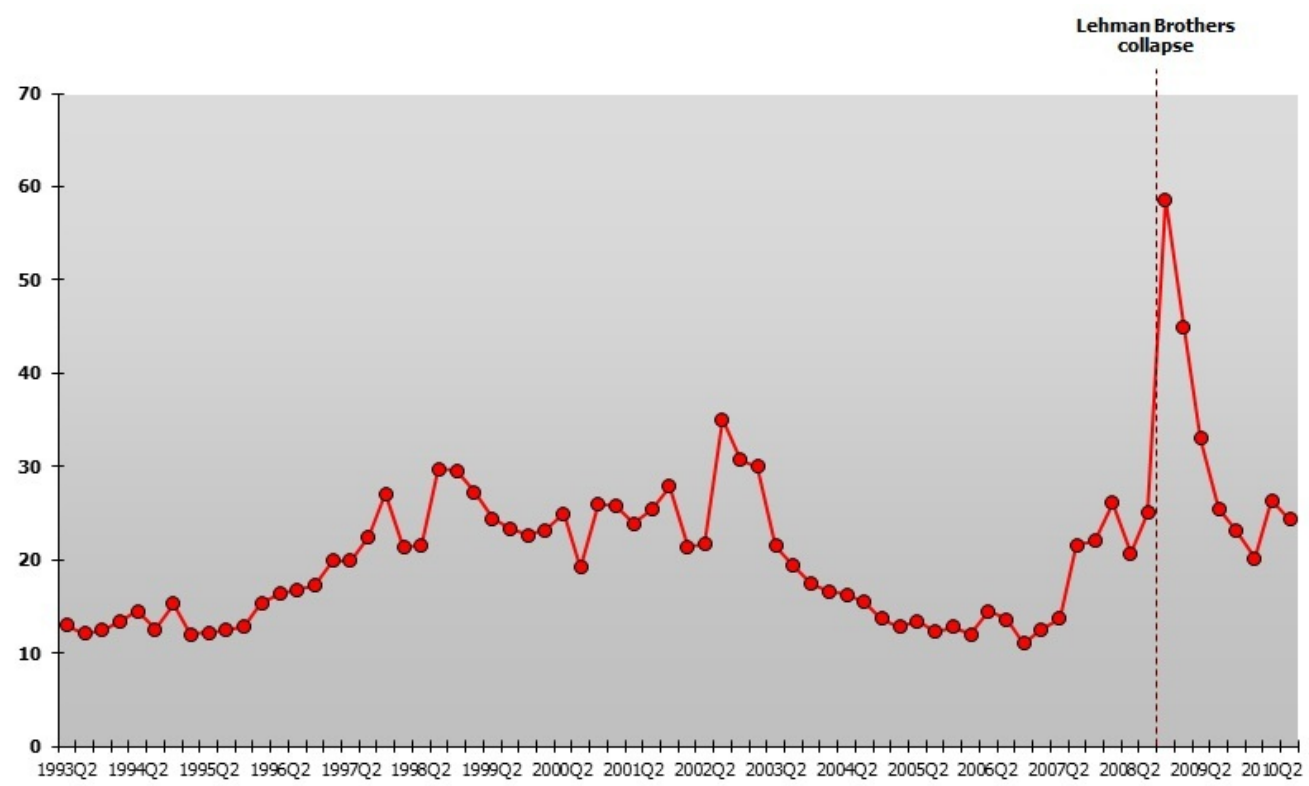

Figure 5: Average VIX-index 
Overall, it thus seems that the VIX-index is relatively stable and might therefore be slightly less informative over time.

Regarding the bond ratings (see figure 6), it can be verified that they slowly decline over time with large drops around 1998 and 2008.

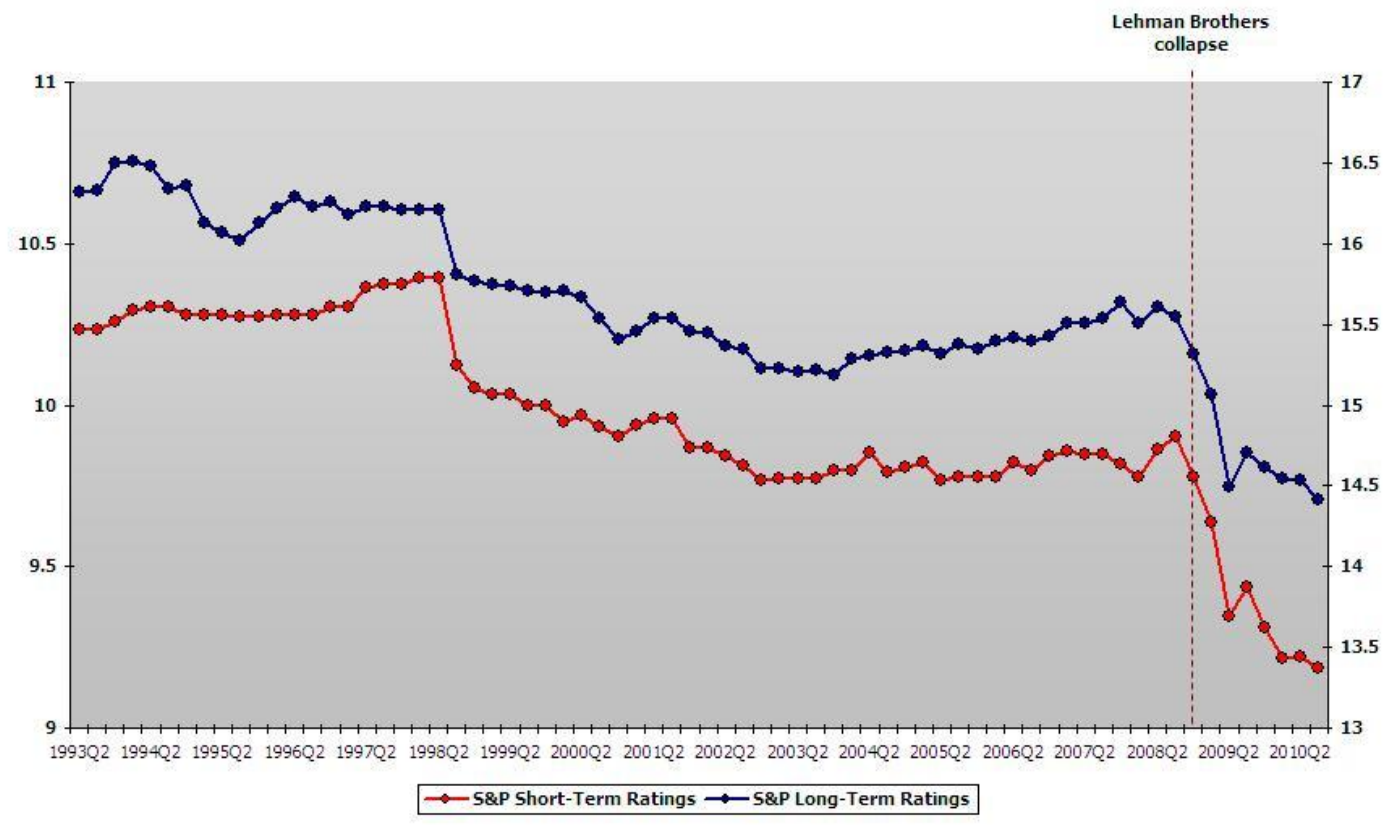

Figure 6: Average S\&P Ratings

Furthermore, the pattern is almost similar for both the short term and long term. Checking for any sample selection issues, we find that only the SIZE variable is statistically significant between the rating and the no-rating group at the $5 \%$ level, while the others (MBratio, STDEVROA and LEV) are not.

\subsection{Empirical Framework and Estimation Methodology}

The basic valuation equation is:

$$
\begin{aligned}
\text { MBratio }_{i, t}= & \operatorname{STDEVROA}_{i, t} \cdot \beta_{1}+\operatorname{STDEVROALEH}_{i, t} \cdot \beta_{2}+\operatorname{STDEVROALEV}_{i, t} \cdot \beta_{3} \\
& +\operatorname{VIX}_{t} \cdot \beta_{4}+\mathrm{VIXLEH}_{t} \cdot \beta_{5}+\mathrm{MBratio}_{i, t-1} \cdot \gamma_{1}+Z_{i, t-1} \cdot \zeta+U_{i, t}
\end{aligned}
$$

where:

MBratio_i,t

STDEVROA_i,t
$=$ market-to-book ratio of bank $\mathrm{i}$ at time $\mathrm{t}$

$=$ standard deviation of the returns on assets (ROA) of the last 5 quarters of bank $\mathrm{i}$ at time $\mathrm{t}$ 
STDEVROALEH_i,t = standard deviation of the returns on assets (ROA) of the last 5 quarters of bank i at time t multiplied with $L E H$, which is a dummy variable that is 1 after Lehman Brothers collapsed

STDEVROALEV_i,t = standard deviation of the returns on assets (ROA) of the last 5 quarters of bank $i$ at time $t$ multiplied with $L E V$, which is the leverage of bank $i$ at time $t$

VIX_t $t \quad=$ average quarterly VIX index at time $\mathrm{t}$

VIXLEH_t $\quad$ = average quarterly VIX index at time $t$ multiplied with $L E H$

$Z_{-} i, t \quad=$ firm level controls of bank $\mathrm{i}$ at time $\mathrm{t}$ (liquidity ratio, ratio of insured vs. non-insured debt, leverage, return on assets (ROA) and size)

We include valuation once lagged to test whether new information is incorporated immediately or gradually over time.

In order to avoid an endogeneity bias in equation (1), we instrument STDEVROA and the interaction terms STDEVROALEH and STDEVROALEV using a standard 2SLS procedure. Instruments are exogenous variables that are included in the explanatory regression for STDEVROA as explanatory exogenous variables but that do not feature in the MBratio equations. They will be discussed when exploring the STDEVROA regression below (i.e. in equation (4)). Another econometric concern could be that the different variables might be of a different order, and thus not cointegrated which might lead to spurious results. However, If we run DickeyFuller tests on each of the separate variables, we find that none of these follows a unit root process, so this issue does not appear to be relevant here.

We estimate similar equations for the two variables proxying for bond prices. Examining the impact of risk taking leads to the following equations for respectively the S\&P short term (ST) and long term (LT) bond ratings:

$$
\begin{aligned}
& S T \_ \text {adjrating }_{i, t}=\operatorname{STDEVROA}_{i, t} \cdot \beta_{1}+\operatorname{STDEVROALEH} H_{i, t} \cdot \beta_{2}+\operatorname{STDEVROALEV}_{i, t} \cdot \beta_{3} \\
& +V I X_{t} \cdot \beta_{4}+\text { VIXLEH } H_{t} \cdot \beta_{5}+S T \text { _adjrating }{ }_{i, t-1} \cdot \gamma_{1}+Z_{i, t-1} \cdot \zeta+U_{i, t} \\
& L T \_ \text {adjrating }_{i, t}=\operatorname{STDEVROA}_{i, t} \cdot \beta_{1}+\mathrm{STDEVROALEH}_{i, t} \cdot \beta_{2}+\operatorname{STDEVROALEV}_{i, t} \cdot \beta_{3} \\
& +V I X_{t} \cdot \beta_{4}+V I X L E H_{t} \cdot \beta_{5}+L T_{\text {_adjrating }}, \text { Idt-1 }_{1} \cdot \gamma_{1}+Z_{i, t-1} \cdot \zeta+U_{i, t}
\end{aligned}
$$

The dependent variables in equations (2) and (3) require clarification. Since ratings seem to be less reliable as indicators of absolute risk, but do fairly well in representing relative credit risk (Financial Economists Roundtable statement (2008) and World Bank Crisis Response (2009)), we work with the difference between the bond rating of bank $i$ and the average bond rating of all 
banks in the data sample. Applying this methodology to both short term and long term ratings gives the variables STadj_rating and LTadj_rating for relative short term and relative long term bond ratings, respectively. We again use a 2SLS procedure to eliminate simultaneity basis in the same way as applied to shareholder valuations.

Furthermore, to assess the impact of deposit insurance, gambles for resurrection and share price performance on risk taking, the following equation is estimated:

$$
\begin{aligned}
\operatorname{STDEVROA}_{i, t}= & \operatorname{adjRES}_{i, t-1} \cdot \beta_{1}+A V 5 Q R E T_{i, t-1} \cdot \beta_{2}+A V 5 Q R E T L E H_{i, t-1} \cdot \beta_{3} \\
& +V I X_{t} \cdot \beta_{4}+V I X L E H_{t} \cdot \beta_{5}+\operatorname{STDEVROA} A_{i, t-1} \cdot \gamma_{1}+Z_{i, t-1} \cdot \zeta+U_{i, t}
\end{aligned}
$$

Equation (4) measures the impact of deposit insurance on risk taking as follows: DEPratio_i,t-1 equals the ratio between deposits over noninsured liabilities and thus measures the differential impact of insured versus uninsured debt.

Finally, the equation also measures whether gambles for resurrection and share price performance lead to more risk taking. The variable adjRES $i, t-1$ measures the excess level of bad loan provisions (the ratio of reserves for loans likely to go wrong) over total assets held by bank $i$ at time $t$-1. A positive value of the coefficient would indicate that a higher relative reserves ratio increases the subsequent risk taking, in line with theoretical predictions. This should be particularly relevant for highly leveraged banks. Furthermore, by means of the coefficient for leverage $(L E V)$, we can identify if higher leverage implies more risk taking at banks.

Finally, to test for loss aversion, the regression equations will include - beside leverage to measure gambling effects - the relative share price performance measure of the last 5 quarters (av5QRET). To measure whether share performance after Lehman Brothers had any additional impact on subsequent risk taking, an interaction term between av5QRET and $L E H$ is included. Since the market-to-book ratio regression does not contain STDEVROA_i,t-1, adjRES_i,t-1, av5QRET_i,t-1 and av5QRETLEH_i,t-1 and the STDEVROA equation does, these variables are used to instrument STDEVROA_i,t, STDEVROALEH_i,t and STDEVROALEV_i,t in the market to book ratio regression.

\section{Results}

Table 3 lists the results of running equation (1). First of all, market-to-book ratios seem to adjust gradually to new information. The coefficient for the first lag of MBratio is highly significant and around 0.9 , indicating a mean lag of about ten quarters $(1 /(1-0.9)$. 


\begin{tabular}{|c|c|c|c|}
\hline & $\begin{array}{c}(1) \\
\text { MBratio }\end{array}$ & $\begin{array}{c}(2) \\
\text { MBratio }\end{array}$ & $\begin{array}{c}(3) \\
\text { MBratio }\end{array}$ \\
\hline L.MBratio & $\begin{array}{c}0.918^{* * * *} \\
(318.76)\end{array}$ & $\begin{array}{c}0.915^{* * * *} \\
(305.31)\end{array}$ & $\begin{array}{c}0.914^{* * * *} \\
(295.45)\end{array}$ \\
\hline stdevroa & $\begin{array}{c}0.571^{* * *} \\
(6.15)\end{array}$ & $\begin{array}{c}-1.920^{* * * *} \\
(-3.08)\end{array}$ & $\begin{array}{c}-17.49^{*} \\
(-1.92)\end{array}$ \\
\hline stdevroaLEH & & $\begin{array}{c}3.741^{* * * *} \\
(4.04)\end{array}$ & $\begin{array}{l}2.119 \\
(1.61)\end{array}$ \\
\hline stdevroaLEV & & & $\begin{array}{l}18.55^{*} \\
(1.71)\end{array}$ \\
\hline L.LIQratio & $\begin{array}{c}-0.278^{* * * *} \\
(-3.89)\end{array}$ & $\begin{array}{c}-0.197^{* * * *} \\
(-2.61)\end{array}$ & $\begin{array}{c}-0.296 * * * \\
(-3.13)\end{array}$ \\
\hline L.LIQratioLEH & $\begin{array}{c}0.0287^{* * * *} \\
\quad(3.13)\end{array}$ & $\begin{array}{c}-0.00710 \\
(-0.55)\end{array}$ & $\begin{array}{c}-0.00358 \\
(-0.28)\end{array}$ \\
\hline L.LIQratioLEV & $\begin{array}{c}0.328^{* * *} \\
(4.17)\end{array}$ & $\begin{array}{c}0.246^{* * *} \\
(2.97)\end{array}$ & $\begin{array}{c}0.353^{* * *} \\
(3.42)\end{array}$ \\
\hline averagevix & $\begin{array}{c}-0.000317^{* * *} \\
(-10.50)\end{array}$ & $\begin{array}{c}-0.000254^{* * *} \\
(-7.37)\end{array}$ & $\begin{array}{c}-0.000281^{* * * *} \\
(-7.48)\end{array}$ \\
\hline VIXLEH & $\begin{array}{c}-0.000158^{* * * *} \\
(-6.58)\end{array}$ & $\begin{array}{c}-0.000310^{* * *} \\
(-6.92)\end{array}$ & $\begin{array}{c}-0.000250^{* * * *} \\
(-4.44)\end{array}$ \\
\hline L.DEPratio & $\begin{array}{c}0.0000123 \\
(1.47)\end{array}$ & $\begin{array}{c}0.00000567 \\
(0.65)\end{array}$ & $\begin{array}{c}0.00000206 \\
(0.23)\end{array}$ \\
\hline L.LEV & $\begin{array}{c}-0.00225 \\
(-0.31)\end{array}$ & $\begin{array}{c}-0.0172^{* *} \\
(-2.08)\end{array}$ & $\begin{array}{c}-0.0692^{* * *} \\
(-2.20)\end{array}$ \\
\hline L.ROA & $\begin{array}{c}0.944^{* * *} \\
(14.89)\end{array}$ & $\begin{array}{c}1.030^{* * *} \\
(15.16)\end{array}$ & $\begin{array}{c}1.287^{* * *} * \\
(7.82)\end{array}$ \\
\hline L.SIZE & $\begin{array}{c}0.000517^{* * * *} \\
(4.36)\end{array}$ & $\begin{array}{c}0.000531^{* * * *} \\
(4.39)\end{array}$ & $\begin{array}{c}0.000568^{* * * *} \\
(4.66)\end{array}$ \\
\hline _cons & $\begin{array}{c}0.0873^{* * * *} \\
(11.91)\end{array}$ & $\begin{array}{c}0.104^{* * *} \\
(12.21)\end{array}$ & $\begin{array}{c}0.151^{* * * *} \\
(5.21)\end{array}$ \\
\hline$N$ & 18208 & 18208 & 18208 \\
\hline$R^{2}$ & 0.89 & 0.89 & 0.89 \\
\hline
\end{tabular}

Table 3: Determinants of Market-to-Book Ratio

If the equation is estimated without any distinction between before and after Lehman coefficients (column 1 in Table 3), the results indicate a clearly and strongly positive link between risks taken and valuation: the choice for a more risky asset portfolio leads to higher valuations (specifically to a higher market to book ratio, in line with hypothesis 1 ). The evidence on risk taking and valuation becomes somewhat more ambiguous once one distinguishes before and after Lehman (column 2 in Table 3): including a Lehman dummy reveals that the impact of idiosyncratic portfolio risk on valuation was negative before the Lehman bankruptcy, but positive thereafter: the sum of the coefficients on STDEVROA and STDEVROALEH is significantly positive. So risk taking was only rewarded after the Lehman Brothers collapse, since the 
coefficient of STDEVROA without the Lehman dummy is negative and significant when adding STDEVROALEH. The mechanism becomes clear by looking at the third column in table 3 . There we added an interaction term with leverage (STDEVROALEV).

That shows that the positive relationship between risk taking and market valuations only holds for banks that are sufficiently leveraged. The latter is consistent with hypothesis 3 . And the independent impact of the Lehman collapse dummy on the risk shifting coefficient turns insignificant once the leverage interaction term is included. Hence, the results clearly show that the asset value collapse after Lehman, and the resulting high leverage and undercapitalization are the drivers of risk shifting and not the changed economic conditions due to the failure of Lehman Brothers per se. It does highlight what Brunnermeier (2009) calls an amplifying spiral: weak balance sheets seem to lead to more risk taking and with ensuing risk of further balance sheet weakening. We will investigate this amplifier mechanism further when estimating an equation for STDEVROA.

This view is confirmed when inspecting the coefficients of the VIX index and its interaction with Lehman Brothers, because there a different pattern emerges. The VIX-index is negatively related to market-to-book valuations before Lehman, but even more so thereafter. So general risks as measured by the "environment variable" VIX have a negative impact on valuation, but risks taken by management have a positive impact at least when leverage is high enough.

Furthermore, the regression outcomes also indicate a small but admittedly insignificant preference for insured vs. uninsured debt since the coefficient of DEPratio is positive but insignificant. Finally, the coefficient for leverage alone is negative, thus affirming that leverage alone is not preferred by shareholders, only in combination with sufficiently high risks and the associated put option for the shareholder that is embedded in high debt.

What is interesting moreover, are the coefficients of LIQratio and LIQratioLEV. The latter is and interaction term between liquidity ratio and leverage. Highly leveraged banks that have a relatively high liquidity ratio are more highly valued. This seems at variance at first sight with the results on the impact of STDEVROA, since the latter is lowered by holding more liquid assets. This suggests that there may be some heterogeneity: some banks go for more risk taking and reward shareholders through shifting risk to debt holders, but some go for more safety, which is also rewarded by shareholders ${ }^{1}$. Finally, ROA and SIZE are positively related to market-to-book valuations.

\footnotetext{
${ }^{1}$ See Bijkerk and Van Wijnbergen (2010) on the possibility of signaling through holding liquidity in higher leveraged banks.
} 


\subsection{Robustness Checks}

The results suggesting the crucial role of leverage in the relation between asset portfolio riskiness and valuation are confirmed when the sample is split in two, separating low leverage banks from high leverage banks². This allows for more differences than just including an interaction term between STDEVROA with leverage does. Rerunning equation (1) for the two leverage groups yields the results listed in Table 4 below:

\begin{tabular}{|c|c|c|}
\hline & $\begin{array}{c}\text { (1) } \\
\text { MBratio } \\
\text { low LEV }\end{array}$ & $\begin{array}{c}(2) \\
\text { MBratio } \\
\text { high LEV }\end{array}$ \\
\hline L.MBratio & $\begin{array}{c}0.908^{* * *} \\
(78.31)\end{array}$ & $\begin{array}{c}0.940^{* * *} \\
(222.75)\end{array}$ \\
\hline stdevroa & $\begin{array}{l}6.676 \\
(0.13)\end{array}$ & $\begin{array}{c}-30.04^{* * * *} \\
(-3.56)\end{array}$ \\
\hline stdevroaLEH & $\begin{array}{c}6.663^{* *} \\
(2.16)\end{array}$ & $\begin{array}{l}2.098 \\
(1.54)\end{array}$ \\
\hline stdevroaLEV & $\begin{array}{l}-11.77 \\
(-0.19)\end{array}$ & $\begin{array}{c}30.88^{* * * *} \\
(3.31)\end{array}$ \\
\hline L.LIQratio & $\begin{array}{l}0.117 \\
(0.12)\end{array}$ & $\begin{array}{c}0.978^{* * *} * \\
(3.28)\end{array}$ \\
\hline L.LIQratioLEH & $\begin{array}{c}-0.0132 \\
(-0.64)\end{array}$ & $\begin{array}{c}-0.0191 \\
(-1.09)\end{array}$ \\
\hline L.LIQratioLEV & $\begin{array}{l}-0.108 \\
(-0.10)\end{array}$ & $\begin{array}{c}-1.018^{* * *} \\
(-3.19)\end{array}$ \\
\hline averagevix & $\begin{array}{c}-0.000275^{* * *} \\
(-4.53)\end{array}$ & $\begin{array}{c}-0.000285^{* * * *} \\
(-6.72)\end{array}$ \\
\hline VIXLEH & $\begin{array}{c}-0.000347^{* * * *} \\
(-4.71)\end{array}$ & $\begin{array}{c}-0.000151^{* *} \\
(-2.51)\end{array}$ \\
\hline L.DEPratio & $\begin{array}{c}-0.0000120 \\
(-0.87)\end{array}$ & $\begin{array}{c}0.0000270^{* * *} \\
(2.32)\end{array}$ \\
\hline L.LEV & $\begin{array}{c}0.0506 \\
(0.18)\end{array}$ & $\begin{array}{c}-0.0264 \\
(-0.89)\end{array}$ \\
\hline L.ROA & $\begin{array}{l}1.908 \\
(1.36)\end{array}$ & $\begin{array}{c}0.568^{* * *} \\
(7.66)\end{array}$ \\
\hline L.SIZE & $\begin{array}{c}0.000140 \\
(0.54)\end{array}$ & $\begin{array}{c}0.000688^{* * * *} \\
(5.13)\end{array}$ \\
\hline _cons & $\begin{array}{c}0.0528 \\
(0.21)\end{array}$ & $\begin{array}{c}0.0858^{* * *} \\
(3.10)\end{array}$ \\
\hline$N$ & 7557 & 9484 \\
\hline$R^{2}$ & 0.87 & 0.91 \\
\hline
\end{tabular}

Table 4: Determinants of Market-to-Book Ratio (split by LEVERAGE)

2 Where low (high) stands for below (above) the median value of 0.9078052 . 
For low leverage banks (column 1 in table 4) there is no overall significant effect of riskier portfolio choices on valuation, at least not before Lehman. After Lehman the impact does become significant and positive: choosing a riskier asset mix is rewarded after Lehman, also for low leverage banks, and independently of where in the lower half of the distribution of leverage they are located: the interaction term with leverage is not significant. For the high leverage banks, the results of Table 3 are replicated: a negative impact without interacting with leverage but a large upward shift in the relevant coefficient (making the net impact positive) once it is interacted with leverage. So the impact of entrepreneurial risk taking positively impacts valuation only for the more leveraged banks among the upper half of the distribution of the leverage ratio. And also a substantial increase after Lehman for all leverage groups within this subsample (the upper half of the distribution). Only there does choosing for higher volatility increase the implied value of the put option implicit in debt contracts sufficiently to actually increase shareholder valuation. In fact the coefficient values imply a switching point at a leverage ratio of $\mathbf{9 7 \%}$, above $\mathbf{9 7 \%}$ the positive impact of riskier portfolio choice on share valuation obtains. Incidentally this would make the new Basel III leverage ratio requirement of 97\% (in our definition) just sufficient to eliminate the perverse link between risk shifting and share valuation.

Another interesting finding in table 4 is that the liquidity signaling effect is only relevant for higher leveraged banks, but only among those within the highly leveraged group that are not too leveraged: the signaling effect obtains for leverage values below $96 \%$. This seems to support our earlier conclusion that extremely leveraged firms profit from riskier portfolio choice, but that at lower leverage banks are better off signaling a more conservative attitude towards risk taking by choosing a higher liquidity ratio.

Finally, there is indeed a preference for insured debt at higher leveraged banks since the coefficient of DEPratio is positive and significant among higher leverage banks. This implies that deposit insurance does indeed lead higher leverage banks to profit from more risk taking.

\subsection{Is the Extra Risk Costly for Debt Holders?}

So far we have found that risk shifting is reflected in higher valuation of equity for higher leverage firms and to a lesser extent for low leverage firms after Lehman. Of course changing asset allocation at market prices cannot change the asset value over all, so one would expect to see the mirror image of these results in debt pricing: the increase in the value of the implicit put option extended by debt holders triggered by higher asset return volatility is at the expense of debt holders. Empirically the issue is non-trivial because we have only proxies for debt valuation, and we cannot price all components of total debt. 
Running equations 2 and 3 from section 3 yields the output of table 5 .

\begin{tabular}{|c|c|c|c|c|c|c|}
\hline & $\begin{array}{c}(1) \\
\text { STadj_rating } \\
\text { all } \\
\end{array}$ & $\begin{array}{c}(2) \\
\text { LTadj_rating } \\
\text { all } \\
\end{array}$ & $\begin{array}{c}(3) \\
\text { STadj_rating } \\
\text { low LEV }\end{array}$ & $\begin{array}{c}(4) \\
\text { LTadj_rating } \\
\text { low LEV }\end{array}$ & $\begin{array}{c}(5) \\
\text { STadj_rating } \\
\text { high LEV }\end{array}$ & $\begin{array}{c}6) \\
\text { LTadj_rating } \\
\text { high LEV }\end{array}$ \\
\hline L.STadj_rating & $\begin{array}{c}0.824^{* * *} \\
(11.98)\end{array}$ & & $\begin{array}{l}0.606^{*} \\
(1.95)\end{array}$ & & $\begin{array}{c}0.976^{* * *} \\
(49.97)\end{array}$ & \\
\hline L.LTadj_rating & & $\begin{array}{c}0.966^{* * *} \\
(117.43)\end{array}$ & & $\begin{array}{c}0.929 * * * \\
(51.30)\end{array}$ & & $\begin{array}{c}0.971^{* * *} * \\
(61.96)\end{array}$ \\
\hline stdevroa & $\begin{array}{l}4279.4 \\
(1.07)\end{array}$ & $\begin{array}{l}103.5 \\
(0.05)\end{array}$ & $\begin{array}{l}7003.0 \\
(0.56)\end{array}$ & $\begin{array}{c}-3347.8^{*} \\
(-1.65)\end{array}$ & $\begin{array}{c}5458.5^{* *} \\
(2.06)\end{array}$ & $\begin{array}{c}3201.7 \\
(0.28)\end{array}$ \\
\hline stdevroaLEH & $\begin{array}{c}-458.8^{*} \\
(-1.81)\end{array}$ & $\begin{array}{c}-236.5^{* *} \\
(-2.48)\end{array}$ & $\begin{array}{l}-964.4 \\
(-0.75)\end{array}$ & $\begin{array}{l}-153.4 \\
(-1.26)\end{array}$ & $\begin{array}{c}-153.7^{*} \\
(-1.86)\end{array}$ & $\begin{array}{l}-74.22 \\
(-1.14)\end{array}$ \\
\hline stdevroaLEV & $\begin{array}{c}-4444.8 \\
(-1.03)\end{array}$ & $\begin{array}{l}30.87 \\
(0.01)\end{array}$ & $\begin{array}{c}-7011.5 \\
(-0.54)\end{array}$ & $\begin{array}{c}3885.6^{*} \\
(1.75)\end{array}$ & $\begin{array}{c}-5920.9^{* *} \\
(-2.03)\end{array}$ & $\begin{array}{c}-3486.9 \\
(-0.28)\end{array}$ \\
\hline L.LIQratio & $\begin{array}{l}-4.463 \\
(-0.64)\end{array}$ & $\begin{array}{l}1.092 \\
(0.28)\end{array}$ & $\begin{array}{l}41.46 \\
(0.84)\end{array}$ & $\begin{array}{l}12.49 \\
(1.36)\end{array}$ & $\begin{array}{l}2.283 \\
(0.45)\end{array}$ & $\begin{array}{l}7.254 \\
(0.50)\end{array}$ \\
\hline L.LIQratioLEH & $\begin{array}{c}2.336^{*} \\
(1.66)\end{array}$ & $\begin{array}{l}1.134^{*} \\
(1.81)\end{array}$ & $\begin{array}{l}4.737 \\
(0.79)\end{array}$ & $\begin{array}{l}0.723 \\
(0.96)\end{array}$ & $\begin{array}{c}1.085^{* *} \\
(2.22)\end{array}$ & $\begin{array}{l}0.723 \\
(0.82)\end{array}$ \\
\hline L.LIQratioLEV & $\begin{array}{l}4.545 \\
(0.62)\end{array}$ & $\begin{array}{l}-0.934 \\
(-0.23)\end{array}$ & $\begin{array}{l}-50.01 \\
(-0.83)\end{array}$ & $\begin{array}{l}-13.41 \\
(-1.28)\end{array}$ & $\begin{array}{l}-2.480 \\
(-0.46)\end{array}$ & $\begin{array}{l}-7.629 \\
(-0.49)\end{array}$ \\
\hline averagevix & $\begin{array}{c}-0.00745^{*} \\
(-1.72)\end{array}$ & $\begin{array}{c}-0.00564^{* *} \\
(-2.57)\end{array}$ & $\begin{array}{c}-0.0224 \\
(-0.63)\end{array}$ & $\begin{array}{c}-0.00418 \\
(-0.68)\end{array}$ & $\begin{array}{c}-0.000681 \\
(-0.40)\end{array}$ & $\begin{array}{c}-0.00116 \\
(-0.60)\end{array}$ \\
\hline VIXLEH & $\begin{array}{c}0.0137 \\
(1.60)\end{array}$ & $\begin{array}{c}0.00575 \\
(1.52)\end{array}$ & $\begin{array}{c}0.0384 \\
(0.69)\end{array}$ & $\begin{array}{c}0.00308 \\
(0.43)\end{array}$ & $\begin{array}{c}0.00115 \\
(0.41)\end{array}$ & $\begin{array}{c}-0.00300 \\
(-1.02)\end{array}$ \\
\hline L.DEPratio & $\begin{array}{c}-0.00110 \\
(-0.25)\end{array}$ & $\begin{array}{c}-0.00683 \\
(-1.61)\end{array}$ & $\begin{array}{c}0.0188 \\
(0.68)\end{array}$ & $\begin{array}{c}-0.00223 \\
(-0.35)\end{array}$ & $\begin{array}{c}0.00634 \\
(0.69)\end{array}$ & $\begin{array}{c}0.00931 \\
(0.89)\end{array}$ \\
\hline L.LEV & $\begin{array}{l}5.007 \\
(1.16)\end{array}$ & $\begin{array}{l}-0.223 \\
(-0.10)\end{array}$ & $\begin{array}{l}22.03 \\
(0.71)\end{array}$ & $\begin{array}{l}-1.320 \\
(-0.35)\end{array}$ & $\begin{array}{l}3.483 \\
(1.42)\end{array}$ & $\begin{array}{l}2.532 \\
(0.22)\end{array}$ \\
\hline L.ROA & $\begin{array}{l}-1.850 \\
(-0.11)\end{array}$ & $\begin{array}{l}1.880 \\
(0.20)\end{array}$ & $\begin{array}{l}7.399 \\
(0.17)\end{array}$ & $\begin{array}{c}27.40^{* *} \\
(2.58)\end{array}$ & $\begin{array}{l}-9.927 \\
(-0.98)\end{array}$ & $\begin{array}{l}4.590 \\
(0.32)\end{array}$ \\
\hline L.SIZE & $\begin{array}{c}-0.0168 \\
(-0.98)\end{array}$ & $\begin{array}{l}0.0113 \\
(1.06)\end{array}$ & $\begin{array}{c}-0.0184 \\
(-0.25)\end{array}$ & $\begin{array}{c}0.0515^{* *} \\
(2.01)\end{array}$ & $\begin{array}{c}0.00847 \\
(0.92)\end{array}$ & $\begin{array}{c}0.0264^{*} \\
(1.83)\end{array}$ \\
\hline _cons & $\begin{array}{l}-4.370 \\
(-1.17)\end{array}$ & $\begin{array}{l}0.282 \\
(0.14)\end{array}$ & $\begin{array}{l}-19.65 \\
(-0.73)\end{array}$ & $\begin{array}{l}0.905 \\
(0.28)\end{array}$ & $\begin{array}{l}-3.272 \\
(-1.39)\end{array}$ & $\begin{array}{l}-2.471 \\
(-0.23)\end{array}$ \\
\hline$N$ & 1157 & 1327 & 421 & 426 & 650 & 804 \\
\hline$R^{2}$ & 0.47 & 0.95 & 0.00 & 0.93 & 0.87 & 0.97 \\
\hline
\end{tabular}

Table 5: Determinants of S\&P Short Term and Long Term Ratings

First of all, we once again find gradual adjustment, as witnessed by high coefficients on the lag terms, with one notable (relative) exception, short term debt ratings in low leverage banks, where the mean lag is considerably shorter (2.5 quarters instead of over 10). Mirroring our share valuation results, short term relative ratings of high leverage banks are significantly negatively affected by an increase in risk taking above a leverage ratio of approximately $92 \%$ (see column (5)). This is consistent with hypothesis 2 . Note that this cutoff point is close to (and not significantly different from) the switching point for leverage found in the market valuation regressions (97\%). Similar coefficient values obtain for the long term ratings regressions, although they are not estimated with precision: the relevant coefficient (and certainly their difference) are insignificant. On the contrary, column (4) shows that for low leverage banks long 
term relative ratings were positively associated with risk taking in a leverage range of about 8590\%: this is consistent with the results from the share price exercise (see also Bijkerk and van Wijnbergen (2012) on the relation between volatility and liquidity signaling).

Furthermore, an increase in general market risk (proxied by the VIX index) has a negative impact on ratings, across all leverage segments; and the interaction term with the Lehman dummy is not significant. Oddly enough, the impact becomes insignificant when the sample is split into low and high leverage banks. Moreover, we also find indications that liquidity has signaling value in debt ratings since Lehman Brothers, which makes sense given the liquidity shortages during the financial crisis: if obtaining liquidity is more expensive, it also becomes more effective as a signaling device. The leverage interaction terms are negative, although generally not significantly so. Further research is needed but a pattern seems to be emerging where high leverage firms and low level banks are differentiated, with the high leverage banks pursuing riskier asset management and with low leverage banks going for higher liquidity and lower risk.

\subsection{The Main Driver(s) of Risk Taking}

Now that we have established that risk taking is positively valued by shareholders of high leverage banks but has a negative impact on (short term) bond ratings of the same high leverage banks, we address the logical next question: given the valuation effect of given asset allocation choices, what are the drivers of these choices? In the theory section, we have identified three potential drivers of increases in risk taking: the deposit guarantee system, high leverage and the associated opportunity to shift risk to debt holders through asset substitution, and, thirdly and more in line with behavioral finance considerations, a penchant for making up for past losses (gambles for resurrection).

Table 6 on the next page summarizes the results of confronting equation (4) with the data. Column (1) contains the results of the regression on the complete sample, while the second and third column show the output for low and high leverage banks. The first coefficient of interest is DEPratio, which measures the effect of insured vs. non-insured debt: a high value indicates a high ratio of insured over uninsured debt. All columns reveal no significant evidence that deposit insurance significantly changes risk taking behaviour: having a higher share of deposits insured through the FDIC is apparently not associated with significantly higher risk taking strategies. This conclusion is not altered if we distinguish between low and high leverage banks. One explanation might be that with the deposit guarantee program comes FDIC supervision, with the threat of prompt corrective action, which may have neutralized the risk taking incentives built into the program. Through the threat of prompt corrective action, the FDIC is apparently able to 


\begin{tabular}{|c|c|c|c|}
\hline & $\begin{array}{c}(1) \\
\text { stdevroa } \\
\text { all } \\
\end{array}$ & $\begin{array}{c}(2) \\
\text { stdevroa } \\
\text { low LEV }\end{array}$ & $\begin{array}{c}(3) \\
\text { stdevroa } \\
\text { high } L E V\end{array}$ \\
\hline L.stdevroa & $\begin{array}{c}0.847^{* * * *} \\
(167.10)\end{array}$ & $\begin{array}{c}0.807^{* * * *} \\
(123.24)\end{array}$ & $\begin{array}{c}0.920^{* * *} * \\
(185.96)\end{array}$ \\
\hline L.DEPratio & $\begin{array}{c}-0.000000416 \\
(-0.82)\end{array}$ & $\begin{array}{c}-0.000000485 \\
(-0.97)\end{array}$ & $\begin{array}{c}-0.000000101 \\
(-0.18)\end{array}$ \\
\hline L.adjRES & $\begin{array}{c}0.0215^{* * *} \\
(9.35)\end{array}$ & $\begin{array}{c}0.0164^{* * *} \\
(6.48)\end{array}$ & $\begin{array}{c}0.0121^{* * * *} \\
(5.14)\end{array}$ \\
\hline L.av5QRET & $\begin{array}{c}-0.0000404^{* * * *} \\
(-6.11)\end{array}$ & $\begin{array}{c}-0.000157^{* * * *} \\
(-6.91)\end{array}$ & $\begin{array}{c}-0.0000150^{* * * *} \\
(-3.24)\end{array}$ \\
\hline L.av5QRETLEH & $\begin{array}{c}-0.000869^{* * *} \\
(-3.37)\end{array}$ & $\begin{array}{c}-0.000154 \\
(-0.34)\end{array}$ & $\begin{array}{c}-0.000537^{* * * *} \\
(-2.67)\end{array}$ \\
\hline L.LIQratio & $\begin{array}{c}-0.0138^{* * *} \\
(-3.17)\end{array}$ & $\begin{array}{c}-0.0120^{* * *} \\
(-2.60)\end{array}$ & $\begin{array}{c}-0.00792 \\
(-0.61)\end{array}$ \\
\hline L.LIQratioLEH & $\begin{array}{c}-0.000506 \\
(-0.90)\end{array}$ & $\begin{array}{c}-0.00128^{* *} \\
(-2.04)\end{array}$ & $\begin{array}{c}0.000704 \\
(1.24)\end{array}$ \\
\hline L.LIQratioLEV & $\begin{array}{c}0.0150^{* * *} \\
(3.15)\end{array}$ & $\begin{array}{c}0.0140^{* * * *} \\
(2.63)\end{array}$ & $\begin{array}{c}0.00841 \\
(0.61)\end{array}$ \\
\hline averagevix & $\begin{array}{c}0.00000961^{* * * *} \\
(5.23)\end{array}$ & $\begin{array}{c}0.00000430^{* *} \\
(1.96)\end{array}$ & $\begin{array}{c}0.00000623^{* * * *} \\
(3.67)\end{array}$ \\
\hline VIXLEH & $\begin{array}{c}0.00000939^{* * * *} \\
(6.44)\end{array}$ & $\begin{array}{c}0.00000683^{* * * *} \\
(3.91)\end{array}$ & $\begin{array}{c}0.00000769^{* * * *} \\
(5.57)\end{array}$ \\
\hline L.LEV & $\begin{array}{c}-0.00296 * * * \\
(-6.72)\end{array}$ & $\begin{array}{c}-0.00325^{* * *} \\
(-6.69)\end{array}$ & $\begin{array}{c}-0.00101 \\
(-0.83)\end{array}$ \\
\hline L.ROA & $\begin{array}{c}-0.0594^{* * *} \\
(-16.47)\end{array}$ & $\begin{array}{c}-0.0283^{* * * *} \\
(-5.62)\end{array}$ & $\begin{array}{c}-0.0294^{* * * *} \\
(-9.05)\end{array}$ \\
\hline L.SIZE & $\begin{array}{c}0.0000114^{*} \\
(1.65)\end{array}$ & $\begin{array}{c}0.0000229^{* * * *} \\
(2.63)\end{array}$ & $\begin{array}{c}2.13 \mathrm{e}-08 \\
(0.00)\end{array}$ \\
\hline _cons & $\begin{array}{c}0.00273^{* * * *} \\
(6.82)\end{array}$ & $\begin{array}{l}0.00286^{* * * *} \\
\quad(6.68)\end{array}$ & $\begin{array}{l}0.000980 \\
(0.87)\end{array}$ \\
\hline$N$ & 18385 & 7660 & 9545 \\
\hline$R^{2}$ & 0.74 & 0.73 & 0.89 \\
\hline
\end{tabular}

Table 6: Determinants of Standard Deviation of ROA

prevent an increase in further risk taking in response to the downside risk protection offered by the program.

The second variable of interest is adjRES, which measures the excess level of the Loan Loss reserves ratio of bank $i$ relative to the market average. The variable is included one period lagged since we want to know the impact of beginning of period loan quality on within period portfolio choice. From both columns (2) and (3), we can see that the coefficient is highly significant for both low and high leverage banks. And the marginal impact is unambiguous: higher loan-loss reserves are associated with riskier portfolios. We assume that provisioning is 
dictated by application of accounting standards and as such not an endogenous variable, but the outcome of applying such standards is obviously related to past portfolio/lending choices.

Whatever the dynamics of that variable, higher beginning of period loan loss reserves seem to encourage further risk taking.

The impact of beginning of period leverage per se on within period risk taking is ambiguous: higher leverage implies more benefits of risk shifting, but also possibly more disciplinary control by creditors. For low leverage banks Table 6 indicates that the second effect dominates, for a strong negative impact over all (see the coefficient of $L E V$ in column 2 of Table 6): the coefficient of $L E V$ is negative and significantly so for low leverage banks. For high leverage banks, temptations of risk shifting and the disciplinary effect of higher debt are apparently more in balance: the coefficient becomes insignificant (and much smaller).

The final testable hypothesis concerned the impact of past share price performance (of the bank itself). Past share price performance is measured by the variable av5QRET, again included with a one period lag: we want to know whether poor share price performance in the past encourages or discourages risk taking today. Is there a penchant for making up for past losses, as behavioral finance has suggested? It can be verified in all columns that share price performance has a significant impact on risk taking, consistent with hypothesis 6: past share price losses have a strong impact on current risk taking, with a significantly negative coefficient: higher losses lead to more risk taking, in line with hypothesis 6: higher losses last period lead to a more risky portfolio this period. And the interaction term with the Lehman dummy should worry supervisors: high leverage banks increased their tendency to gamble to make up for past losses after Lehman, the interaction term also gets a negative coefficient. For low leverage banks the interaction term is not significantly different from zero, so they do not seem to have modified their behaviour.

Past losses on the asset portfolio seem to have a similar effect; a negative coefficient on the return on assets variable one period lagged (L.ROA) also indicates that banks respond to poor portfolio performance by taking on more risk, chasing higher yield. Of the other control variables, the coefficients of the VIX variable is of interest: apparently a general increase in market volatility led to higher portfolio risk. Whether that is the consequence of portfolio reallocation or market correlation for a given portfolio composition is impossible to verify on the basis of current data. The coefficient is significantly higher for more leveraged banks.

Overall the results suggest that a mixture of low stock prices, depressed loan portfolios and generally weak balance sheets are a witches brew, leading to more risk taking and the associated risk of getting more of the same in future periods: an amplification cycle, in the terminology of Brunnermeier (2009). 


\section{Conclusions}

This paper deals with the relation between excessive risk taking and capital structure in banks. We follow a dual approach in exploring the relation between capital structure and risk taking. Examining a large quarterly dataset of U.S. banks between 1993 and 2010, we find that equity is valued higher when more risky portfolios are chosen, even controlling for changes in market volatility, but only when leverage is high (leverage ratio above about 30 ). We do present results in line with the expectation of a negative impact of more risk taking on valuation of the debt of highly leveraged banks. Moreover, we also find that liquidity has signaling value in debt ratings since Lehman Brothers. A pattern seems to be emerging from both equity and bond pricing where high leverage firms and low level banks are differentiated, with the high leverage banks pursuing riskier asset management and with low leverage banks going for higher liquidity and lower risk.

Finally, the direct analysis of risk choices (regressions explaining the variance on the bank's asset portfolio) shows no evidence that deposit insurance is encouraging risk taking behaviour. Apparently, the threat of prompt corrective action by the FDIC neutralizes any incentive to increase risk taking in response to the downside risk protection the FDIC provides. We do find that banks with a more troubled loan portfolio are likely to take on more risk, as are banks with higher leverage. Also, banks whose share price has slumped tend to gamble for resurrection by increasing the riskiness of their asset portfolios.

The results suggest that incentives embedded in the capital structure of banks contribute to systemic fragility, and so support the Basel III proposals towards less leverage and higher loss absorption capacity of capital.

\section{References}

Acharya, V.V., H. Mehran, and A. Thakor, "Caught between Scylla and Charybdis? Regulating Bank Leverage When There is Rent Seeking and Risk Shifting", working paper (2011).

Beatty, A., and S. Liao, "Regulatory Capital Ratios, Loan Loss Provisioning and Pro-cyclicality", Working Paper (2009).

Berger, A.N., R. DeYoung, M.J. Flannery, D. Lee and Ö. Öztekin, “How Do Large Banking Organizations Manage Their Capital Ratios?", Journal of Financial Services Research 34, 123-149 (2008).

Bijkerk, S., and S.J.G. van Wijnbergen, "Cash is King? The Influence of Liquidity Requirements on 
Liquidity Signaling by Financial Institutions", mimeo (2012).

Bruche, M., and G. Lobet, “Walking Wounded or Living Dead? Making Banks Foreclose Bad Loans", working paper (2011).

Brunnermeier, M., "Deciphering the Liquidity and Credit Crunch 2007-2008", Journal of Economic Perspectives 23, 77-100 (2009).

Calomiris, C., and C. Kahn, "The Role of Demandable Debt in Structuring Optimal Banking Arrangements", American Economic Review 81, 497-513 (1991).

Cassola, N., C. Holthausen, and M. Lo Luca, "Liquidity: Concepts and Risks", ECB working paper (2008).

Chang, C.-C., Y.-J. Hsiao, Y.-C. Lin, and W.-C. Chen, "Empirically Re-examining the Risk Shifting in Financially Distressed Firms", working paper (2009).

Diamond, D.W., and R.G. Rajan, "Liquidity risk, liquidity creation and financial fragility: A theory of banking", Journal of Political Economy 109, 287-327 (2001).

Diamond, D.W., and R.G. Rajan, "Fear of Firesales, illiquidity seeking and Credit Freezes", Quarterly Journal of Economics (2011)

Flannery, M.J., "Financial crises, payment system problems, and Discount Window lending", Journal of Money, Credit and Banking 28, 801-824 (1996).

Jensen, M.C., and W.H. Meckling, "Theory of the firm: Managerial behavior, agency costs, and ownership structure", Journal of Financial Economics 4, 305-360 (1976).

Kahneman, D., and A. Tversky, "Prospect Theory: An Analysis of Decision under Risk", Econometrica 47, 263-291 (1979).

Laeven, L. and R. Levine, "Bank Governance, Regulation and Risk-Taking", Journal of Financial Economics 93, 259-275 (2009).

Merton, R.C., "On the pricing of corporate debt: The risk structure of interest rates", Journal of 
Finance 29, 449-470 (1974).

Ranciere, R., Tornell, A., and F. Westermann, "Systemic Crises and Growth", Quarterly Journal of Economics 123(1): 359-406 (2008).

Reinhart, C. and K. Rogoff (2009), This time is different: eight centuries of Financial Folly, Princeton University Press

Tversky, A., and D. Kahneman, "Loss Aversion in Riskless Choice: A Reference-Dependent Model", Quarterly Journal of Economics 106, 1039-1061 (1991).

Tversky, A., and D. Kahneman, "Advances in Prospect Theory: Cumulative Representation of Uncertainty", Journal of Risk and Uncertainty 5, 297-323 (1992). 